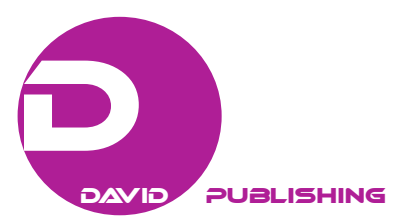

\title{
Grand Strategies for Dealing With Chinese Local Government Debts
}

\author{
Mengzhong Zhang \\ University of Massachusetts Boston, Boston, USA \\ Youwei Qi \\ Rutgers University-Newark, Newark, USA
}

\begin{abstract}
Local governmental debts in China seem to be in a more precarious position than local government debts in the USA. The scale of Chinese local government debts far surpasses that of the USA. Further, Chinese local government debts appear to be expanding at an alarming rate in the past decade or so. This research focuses on grand strategies for dealing with Chinese local government debts. There are five research questions for this paper: 1) What is the size of the Chinese government debts? 2) Are Chinese local government debts controllable? 3) Who or what caused the rapid increase of the Chinese local government debts? 4) Is it possible to have individual accountability for increasing local government debts in the future? and 5) Will it be helpful to create a local government debt management organization in the Chinese central government? Based on the available literature, this analysis also utilizes in death interviews with 13 government officials, policy analyst, and scholars. First, this paper identifies the size and categories of debts related to Chinese local governments. Then this paper illustrates various ways and methods of Chinese local governments to obtain leverage. After analyzing the causes and origins of these debts, the research demonstrates a potential local systematic risk. By contrast to its advantages and disadvantages, the paper suggests that the local governmental debts need to be constrained. It is important to restrict debt growth in terms of issuing, buying, repurchasing, collateralizing, etc. within a legal framework. With the consideration of political mechanisms in China, the research suggests that the central government establishes a specific organization to help normalize the local governmental debts with the function of supervision and management. The research also believes that it will be an effective way to control the growth of local debts if the central government can hold the relevant top leaders/officials of local governments to be accountable for their performances related to debt accumulation.
\end{abstract}

Keywords: debt, debt size, local government, Chinese government, individual, accountability, debt management organization

\section{Introduction}

The fiscal crises in Greece and other countries have resulted in significant concerns over government debt

Mengzhong Zhang, associate professor, Ph.D., John W. McCormack Graduate School of Policy and Global Studies, University of Massachusetts Boston, Boston, USA.

Youwei Qi, MPA, School of Public Affairs and Administration, Rutgers University-Newark, Newark, USA.

Correspondence concerning this article should be addressed to Mengzhong Zhang, Department of Public Policy and Public Affairs, John W. McCormack Graduate School of Policy Studies, University of Massachusetts Boston, 100 Morrissey Boulevard, Boston, MA 02125, USA. 
and its sustainability globally and China is not an exception (Li \& Lin, 2011). Chinese local government debts have increased rapidly in recent years and thus have attracted attention from domestic and abroad commentators alike in various perspectives (Zhao, 2011; He, 2014; Yan, 2012; Haitong, 2014; Anonymity, 2014; Wei \& Davis, 2015; Wildau, 2015; McMahon, 2015; Bloomberg, 2015). Many scholars and observers worry that local government debts in China are on the edge of a cliff and that an effective mechanism of controlling the growth of the debts has yet to be found (Shen, 2014; Nagao, 2015; Talley, 2014; Kwong, 2013; Kuijs, 2010).

Chinese government debts in general and Chinese local government debts in particular are a fairly recent phenomenon. By the end of 2004, it was estimated that Chinese sub-national government debts were close to 2.5 trillion RMB; by the end of 2009, it was estimated that Chinese sub-national government debts were about 10.0 trillion RMB (Zhao, 2011). According to Chinese government official auditing, by the end of June 2013, the direct Chinese local government debts were 10.9 trillion RMB and the indirect (contingent liabilities) Chinese local government debts were about 7.0 trillion RMB. Thus, the total local government debts were 17.9 trillion RMB by the end of June 2013 (Quanguo Zhengfuxing Zhaiwu, 2013). Chinese provincial authorities estimated that they had 16 trillion RMB in direct liabilities earlier this year (2015), and that, the total will surpass 23 trillion RMB including the contingent liabilities (Bloomberg, 2015). If the above figures are reliable, the Chinese local government debts (both direct and indirect liabilities) increased almost 10 times from the end of 2004 to the end of 2014! Both the current debt figure and the rapid increasing rate are alarming. Moreover, it is believed that the Chinese local government debts will become uncontrollable if effective measures are not put in action immediately.

China's local governments have utilized various ways to borrow money. First, Chinese local governments and their affiliated agencies have directly borrowed money in addition to their fiscal revenues and the central government transfer funds (Zheng, 2012). Thus, the public organizations that borrow the money are to some extent out of constraints (Feng, 2013). Second, the local governments are used to utilize Financing Vehicles [commonly called China's Local Government Financing Vehicles (LGFV)] to borrow money. It was estimated that there were more than 10,000 LGFV in 2013 (Zhang, 2013).

Why do so many Chinese local governments have large (and rapidly growing) budget deficits in the first place? It is difficult to find a unified answer. However, the 1994 fiscal reform seemed to have triggered the problem of local government receiving less revenue while bearing increasing responsibility of various public services and thus more expenditure compared to the previous years (M. Zhang, 2006). In addition, there are strong incentives to boost the economy through infrastructure (Zhao, 2004): additional roads, high speed rails, airport, bridges, utilities, homes, lucrative business hubs, and somehow unoccupied ghost towns. The Chinese local government leaders' performances have mainly been measured by the economy development (or GDP) and their promotions depend upon the GDP of local governments to a large extent (Zhao, 2004). Society wants officials to take the long view, but individual government bureaucrat just wants successes to last long enough for them to be promoted elsewhere (Hu, 2008; Jia, Liu, Zhang, Shi, \& Sun, 2010).

The results of such swelling or expanding debts will be difficult to model or predict. Some authors have called it a "time bomb" (Guest Post, 2014; Song, 2013; Nagao, 2015; Zhang, 2013), or a Chinese local government debt crisis (Yan, 2012). Other commentators believe that there is an increasing likelihood of a Detroit-style default (Zhang, 2013). There are many negative consequences of a potential crisis, including decline of the property prices and slow-down of the economy growth, leading to international investment panic and even society-wide chaos (Lin, 2011; Huang, 2011). 
In recent years, Chinese central government has tried different measures to regulate and control the local government debts. However, the results so far are not encouraging and can at best be considered mixed.

Given that the government debts have become a global crisis in general and Chinese local government debts receive a huge concern in particular, it can never be exaggerated for the importance of examining the Chinese local government debts as well as finding solutions. The main purpose of this research is to explore the root causes and origins of the Chinese local government debts and intends to propose solutions by developing targeted strategies and measures. This paper is thus intended to fill the literature gap and propose effective policy recommendations. To this end, this introduction clarifies the importance of the topic and addresses main problems. In section 2 of literature review, the historical evolution of Chinese local government debts will be reviewed; the definition of local debts will be carefully examined; especially, the importance of this study will be highlighted and the unique contribution of this study will be illustrated. In section 3 , the research questions and research methods will be introduced. Section 4 identifies the research findings. Section 5 analyzes the findings and proposes some policy recommendations. Section 6 concludes the paper.

\section{Literature Review}

\section{Size: Historical Evolution of Chinese Local Government Debts}

From Table 1, it can be seen that before the Chinese grand policy of "Reform and Opening to the Outside" in 1978, China had generally tried to balance the budget. In the 29 years from 1953 to 1981, the government as a whole in 17 years has had either a balanced budget or a small surplus, and in the other 12 years had small deficits. It is understandable that China had adopted a budgetary policy called "balanced-budgetary or a-small-surplus policy" for those years. Chinese government has neither accessed to the international capital market nor is accustomed to borrowing money from the public (Li \& Lin, 2011).

Table 1

Revenue Expenditures and Deficits of Central and Local Governments (Billion Yuan)

\begin{tabular}{|c|c|c|c|c|c|c|c|c|c|c|c|}
\hline \multirow[b]{2}{*}{ year } & \multicolumn{4}{|c|}{ Total revenue } & \multicolumn{4}{|c|}{ Total expenditure } & \multicolumn{3}{|c|}{ Deficits } \\
\hline & Total & Central & Local & $\begin{array}{l}\% \text { of } \\
\text { central }\end{array}$ & Total & Central & Local & $\begin{array}{l}\% \text { of } \\
\text { central }\end{array}$ & Total & Central & Local \\
\hline 1953 & 21.32 & 17.7 & 3.62 & 83 & 21.92 & 16.21 & 5.72 & 73.9 & -0.6 & 1.49 & -2.1 \\
\hline 1954 & 24.51 & 18.77 & 5.74 & 76.6 & 24.41 & 18.37 & 6.04 & 75.3 & 0.1 & 0.4 & -0.3 \\
\hline 1955 & 24.92 & 19.34 & 5.58 & 77.6 & 26.27 & 20.1 & 6.18 & 76.5 & -1.35 & -0.76 & -0.6 \\
\hline 1956 & 28.01 & 22.21 & 5.8 & 79.3 & 29.85 & 21 & 8.85 & 70.4 & -1.84 & 1.21 & -3.05 \\
\hline 1957 & 30.32 & 22.29 & 8.02 & 73.5 & 29.59 & 21 & 8.59 & 71 & 0.73 & 1.29 & -0.57 \\
\hline 1958 & 37.96 & 30.52 & 7.43 & 80.4 & 40.03 & 17.72 & 22.31 & 44.3 & -2.07 & 12.8 & -14.88 \\
\hline 1959 & 48.71 & 11.87 & 36.83 & 24.4 & 54.31 & 24.93 & 29.38 & 45.9 & -5.6 & -13.06 & 7.45 \\
\hline 1960 & 57.23 & 14.28 & 42.95 & 25 & 64.37 & 27.86 & 36.51 & 43.3 & -7.14 & -13.58 & 6.44 \\
\hline 1961 & 35.6 & 7.66 & 27.94 & 21.5 & 35.6 & 16.03 & 19.57 & 45.0 & 0 & -8.37 & 8.37 \\
\hline 1962 & 31.55 & 9.3 & 22.04 & 29.7 & 29.48 & 18.16 & 11.32 & 61.6 & 1.87 & -8.86 & 10.72 \\
\hline 1963 & 34.22 & 7.89 & 26.33 & 23.1 & 33.2 & 19.23 & 13.97 & 57.9 & 1.02 & -11.34 & 12.36 \\
\hline 1964 & 39.95 & 10.08 & 29.87 & 25.2 & 39.37 & 22.48 & 16.89 & 57.1 & 0.58 & -12.4 & 12.98 \\
\hline 1965 & 47.33 & 15.61 & 31.73 & 33.0 & 46.00 & 28.42 & 17.58 & 61.8 & 1.33 & -12.81 & 14.15 \\
\hline 1966 & 55.87 & 19.64 & 36.22 & 35.2 & 53.76 & 33.91 & 19.85 & 63.1 & 2.11 & -14.27 & 16.37 \\
\hline 1967 & 41.93 & 13.24 & 28.96 & 31.6 & 43.98 & 26.99 & 16.99 & 61.4 & -2.05 & -13.75 & 11.7 \\
\hline 1968 & 36.12 & 10.71 & 25.41 & 29.6 & 35.78 & 21.94 & 13.83 & 61.3 & 0.34 & -11.23 & 11.58 \\
\hline 1969 & 52.67 & 17.11 & 35.56 & 32.5 & 52.58 & 31.91 & 20.67 & 60.7 & 0.09 & -14.8 & 14.89 \\
\hline
\end{tabular}


Table 1 continued

\begin{tabular}{|c|c|c|c|c|c|c|c|c|c|c|c|}
\hline 1970 & 66.29 & 18.3 & 48 & 27.6 & 64.94 & 38.24 & 26.7 & 58.9 & 1.35 & -19.94 & 21.3 \\
\hline 1971 & 74.47 & 11.93 & 62.53 & 16.0 & 73.21 & 43.56 & 29.65 & 59.5 & 1.26 & -31.63 & 32.88 \\
\hline 1972 & 76.65 & 10.58 & 66.07 & 13.8 & 76.58 & 43.14 & 33.44 & 56.3 & 0.07 & -32.56 & 32.63 \\
\hline 1973 & 80.96 & 11.98 & 68.98 & 14.8 & 80.87 & 44.93 & 35.94 & 55.6 & 0.09 & -32.95 & 33.04 \\
\hline 1974 & 78.31 & 13.47 & 64.83 & 17.2 & 79.02 & 39.78 & 39.24 & 50.3 & -0.71 & -26.31 & 25.59 \\
\hline 1975 & 81.56 & 9.66 & 71.9 & 11.8 & 82.09 & 40.94 & 41.15 & 49.9 & -0.53 & -31.28 & 30.75 \\
\hline 1976 & 77.66 & 9.89 & 67.77 & 12.7 & 80.62 & 37.76 & 42.86 & 46.8 & -2.96 & -27.87 & 24.91 \\
\hline 1977 & 87.45 & 11.39 & 76.06 & 13.0 & 84.35 & 39.37 & 44.98 & 46.7 & 3.10 & -27.98 & 31.08 \\
\hline 1978 & 113.23 & 17.58 & 95.65 & 15.5 & 112.21 & 53.21 & 59.00 & 47.4 & 1.02 & -35.63 & 36.65 \\
\hline 1979 & 114.64 & 23.13 & 91.5 & 20.2 & 128.18 & 65.51 & 62.67 & 51.1 & -13.54 & -42.38 & 28.83 \\
\hline 1980 & 115.99 & 28.45 & 87.55 & 24.5 & 122.88 & 66.68 & 56.20 & 54.3 & -6.89 & -38.23 & 31.35 \\
\hline 1981 & 117.58 & 31.11 & 86.47 & 26.5 & 113.84 & 62.57 & 51.28 & 55.0 & 3.74 & -31.46 & 35.19 \\
\hline 1982 & 121.23 & 34.68 & 86.55 & 28.6 & 123.00 & 65.18 & 57.82 & 53.0 & -1.77 & -30.50 & 28.73 \\
\hline 1983 & 136.7 & 49 & 87.69 & 34.8 & 140.95 & 75.96 & 64.99 & 53.9 & -4.25 & -26.96 & 22.7 \\
\hline 1984 & 164.29 & 66.55 & 97.74 & 40.5 & 170.10 & 89.33 & 80.77 & 52.5 & -5.81 & -22.78 & 16.97 \\
\hline 1985 & 200.48 & 76.96 & 123.52 & 38.4 & 200.43 & 79.53 & 120.9 & 39.7 & 0.05 & -2.57 & 2.62 \\
\hline 1986 & 212.2 & 77.84 & 134.36 & 36.7 & 220.49 & 83.64 & 138.66 & 37.9 & -8.29 & -5.80 & -4.30 \\
\hline 1987 & 219.94 & 73.63 & 146.31 & 33.5 & 226.22 & 84.56 & 141.66 & 37.4 & -6.28 & -10.93 & 4.65 \\
\hline 1988 & 235.72 & 77.48 & 158.25 & 32.9 & 249.12 & 84.50 & 164.62 & 33.9 & -13.4 & -7.02 & -6.37 \\
\hline 1989 & 266.49 & 82.25 & 184.24 & 30.9 & 282.38 & 88.88 & 193.50 & 31.5 & -15.89 & -6.63 & -9.26 \\
\hline 1990 & 293.71 & 99.24 & 194.47 & 33.8 & 308.36 & 100.45 & 207.91 & 32.6 & -14.65 & -1.21 & -13.44 \\
\hline 1991 & 314.95 & 93.83 & 221.12 & 29.8 & 338.66 & 109.08 & 229.58 & 32.2 & -23.71 & -15.25 & -8.46 \\
\hline 1992 & 348.34 & 97.95 & 250.39 & 28.1 & 374.22 & 117.04 & 257.18 & 31.3 & -25.88 & -19.09 & -6.79 \\
\hline 1993 & 434.9 & 95.75 & 339.14 & 22 & 464.23 & 131.21 & 333.02 & 28.3 & -29.33 & -35.46 & 6.12 \\
\hline 1994 & 521.81 & 290.65 & 231.16 & 55.7 & 579.26 & 175.44 & 403.82 & 30.3 & -57.45 & 115.2 & -172.66 \\
\hline 1995 & 624.22 & 325.66 & 298.56 & 52.2 & 682.37 & 199.54 & 482.83 & 29.2 & -58.15 & 126.1 & -184.27 \\
\hline 1996 & 740.8 & 366.11 & 374.69 & 49.4 & 793.76 & 215.13 & 578.63 & 27.1 & -52.96 & 151.0 & -203.94 \\
\hline 1997 & 865.11 & 422.69 & 442.42 & 48.9 & 923.36 & 253.25 & 670.11 & 27.4 & -58.25 & 169.4 & -227.69 \\
\hline 1998 & 987.6 & 489.2 & 498.4 & 49.5 & $1,079.82$ & 312.56 & 767.26 & 28.9 & -92.22 & 176.6 & -268.86 \\
\hline 1999 & $1,144.41$ & 584.92 & 559.49 & 51.1 & $1,318.77$ & 415.23 & 903.53 & 31.5 & -174.36 & 169.7 & -344.04 \\
\hline 2000 & 1,338.01 & 698.61 & 551.43 & 52.1 & $1,587.94$ & 551.43 & $1,036.51$ & 34.7 & -249.93 & 147.2 & -485.08 \\
\hline 2001 & 1,637.1 & 857.8 & 779.3 & 52.4 & $1,884.4$ & 575.4 & 1,309.0 & 30.5 & -247.3 & 282.4 & -529.7 \\
\hline 2002 & $1,801.5$ & $1,004.2$ & 797.3 & 55.7 & $2,111.3$ & 641.2 & $1,470.1$ & 30.4 & -309.8 & 363.0 & -672.8 \\
\hline 2003 & $2,171.5$ & $1,186.5$ & 985.0 & 54.6 & $2,465.0$ & 742.0 & 1,723.0 & 30.1 & -293.5 & 444.5 & -738.0 \\
\hline 2004 & 2,639.6 & $1,450.3$ & 1,189.3 & 54.9 & $2,848.7$ & 789.4 & $2,059.3$ & 27.7 & -209.0 & 660.9 & -869.9 \\
\hline 2005 & $3,164.9$ & $1,654.9$ & $1,510.1$ & 52.3 & 3,393.0 & 877.6 & $2,515.4$ & 25.9 & -228.1 & 777.3 & $-1,005.4$ \\
\hline 2006 & $3,876.0$ & $2,045.7$ & $1,830.4$ & 52.8 & $4,042.3$ & 999.1 & $3,043.1$ & 24.7 & -166.3 & $1,046.5$ & $-1,212.8$ \\
\hline 2007 & $5,132.2$ & $2,774.9$ & 2,357.3 & 54.1 & 4,978.1 & $1,144.2$ & 3,833.9 & 23.0 & 154.0 & $1,630.7$ & $-1,476.7$ \\
\hline 2008 & 6,133.0 & 3,268.1 & $2,865.0$ & 53.3 & 6,259.3 & $1,334.4$ & $4,924.8$ & 21.3 & -126.2 & 1,933.6 & $-2,059.9$ \\
\hline 2009 & $6,847.7$ & 3,589.6 & 3,258.1 & 52.4 & $7,587.4$ & $1,528.0$ & $6,059.4$ & 20.1 & -739.8 & $2,061.6$ & $-2,801.3$ \\
\hline 2010 & 8,318.03 & $4,257.05$ & $4,060.98$ & $51.2 \%$ & 9,318.03 & 1,822.09 & $7,495.94$ & $19.6 \%$ & $-1,000$ & -800 & -200 \\
\hline 2011 & $10,524.00$ & $5,280.62$ & $5,243.39$ & $50.18 \%$ & $11,374.00$ & $1,940.62$ & $9,433.38$ & $17.06 \%$ & -850 & -650 & -200 \\
\hline 2012 & $11,991.00$ & $5,883.24$ & $6,107.73$ & $49.06 \%$ & $12,791.00$ & $1,894.90$ & $10,896.10$ & $14.81 \%$ & -800 & -550 & -250 \\
\hline 2013 & $13,029.26$ & $6,117.38$ & 6,911.89 & $46.95 \%$ & $14,229.26$ & 2,163.61 & $12,065.65$ & $15.21 \%$ & $-1,200$ & -850 & -350 \\
\hline 2014 & $14,134.97$ & $6,549.00$ & 7,585.97 & $46.33 \%$ & $15,484.97$ & $2,338.56$ & $13,146.42$ & $15.10 \%$ & $-1,350$ & -950 & -400 \\
\hline 2015 & $15,530.00$ & $7,023.00$ & $8,507.00$ & $45.22 \%$ & $17,150.00$ & $2,551.20$ & $14,598.80$ & $14.88 \%$ & $-1,620$ & $-1,120$ & -500 \\
\hline
\end{tabular}

Sources: data from 1953 to 2009 taken from the article by Li and Lin (2011); data from 2010 to 2015 from several Chinese Government Reports. 
From 1979 to 1993, Chinese government began to borrow limited capital from foreign and domestic markets. In 1994, the Chinese government's deficit almost doubled and the central government had a surplus from 1994 to 2009 while the local government had a significant increase of deficit ever since. This rapid change can at least partly be explained by the 1994 Chinese tax for fee reform (M. Zhang, 2006). In order to deal with the Asian Financial Crisis that happened in 1997, Chinese government followed an expansionary fiscal policy from 1998, and the budget deficits increased sharply in the following years. To cope with the global financial crisis in 2008, Chinese government adopted an expansionary fiscal policy again. In particular, Chinese central government issued a four trillion RMB rescue package in 2008. Thus, the government deficits reached new heights in the following years.

For the Chinese local governments, it is apparent that the debts began to accumulate since 1994 (Table 1). Ever since 1994, Chinese local governments' bottom line has been red ink and at a significant level of deficits. It was estimated that Chinese sub-national government debts increased from about 2.5 trillion RMB in 2004 to about 10.0 trillion RMB at the end of 2009 (Zhao, 2011). Furthermore, including the contingent liabilities, the Chinese local governments' debts were calculated to be more than 23 trillion RMB in early 2015 (Bloomberg, 2015). According to Nicholas Lardy's estimation (in 2004), explicit and contingent government debt combined was about 10 trillion RMB in 2003, an amount equivalent to about 85 percent of gross domestic product in that year. A recent article estimated that China's total debt equals 282\% of its GDP, and China's total debt over GDP is higher than some advanced economies such as Australia (274\%), United States (269\%), Germany (258\%), and Canada (247\%) (Costa, 2015). Costa’s (2015) study cited the McKinsey Global Institute's analysis, which indicates that "rapid growth in lending by local governments, 'many of which may not be able to repay'” (Costa, 2015).

\section{Categories: Conventional and Authoritative}

Based on Hana's findings, Shangxi Liu categorized Chinese local government debts into four types according to sources of the debts (Table 2), which are grouped into two dimensions in a $2 \times 2$ matrix: validity and risk (An, 2002; H. Zhang, 2006; Hu, 2008). Classification yet varies a little bit considering various definitions by scholars.

Table 2

Four Types of Chinese Local Government Debts

\begin{tabular}{|l|l|l|l|}
\hline \multirow{2}{*}{ Debt } & Risk \\
\cline { 3 - 4 } & High: direct & Low: contingent \\
\hline Validity & $\begin{array}{l}\text { 1. government foreign loans } \\
\text { 2. treasury bond lending } \\
\text { 3. earmarked loans from the central government } \\
\text { 4. loans from domestic financial institutions, } \\
\text { organizations, and individuals }\end{array}$ & $\begin{array}{l}\text { 1. foreign loans guaranteed by local governments } \\
\text { 2. domestic loans guaranteed by local governments } \\
\text { 3. deficits of society security funds }\end{array}$ \\
\cline { 2 - 4 } & Low: covert & $\begin{array}{l}\text { 1. payments in arrears (including salaries and } \\
\text { pensions, construction payments, etc.) } \\
\text { 2. expenditure on substandard public goods and } \\
\text { service (including education, infrastructure, etc.) } \\
\text { 3. society security plans }\end{array}$ & $\begin{array}{l}\text { 1. payments for SOE (state-owned enterprise) } \\
\text { reform } \\
\text { 2. debts unlawfully guaranteed by local governments } \\
\text { 3. bad loans of policy financial institutions } \\
\text { 4. SOEs' debts after local governments' intervention } \\
\text { 5. bad loans and funding gap of local financial } \\
\text { institutions }\end{array}$ \\
\hline
\end{tabular}

In 2009, the Ministry of Finance in China has requested local governments to register their government debts in three different forms (Table 3), which reflects the extent to which local governments would take the accountability if a certain debt default occurred. 
Table 3

Three Forms of Local Government Debts in China

\begin{tabular}{|c|c|c|}
\hline \multicolumn{3}{|l|}{ Responsibility of local governments to bear } \\
\hline $\begin{array}{l}\text { High: Category I } \\
\text { Debt to pay back }\end{array}$ & $\begin{array}{l}\text { Modest: Category II } \\
\text { Liability to guarantee }\end{array}$ & $\begin{array}{l}\text { Low: Category III } \\
\text { Obligation to salvage }\end{array}$ \\
\hline $\begin{array}{l}\text { - local government bonds; } \\
\text { higher level government transferring } \\
\text { financial debt (foreign lending debt, } \\
\text { treasury bond lending, agricultural } \\
\text { comprehensive development loans, and } \\
\text { other financial lending); } \\
\text { - all of investment funds on unproductive } \\
\text { public interest (basic) projects be } \\
\text { transferred as the debts that must be } \\
\text { clearly repaid by the financial funds; } \\
\text { - arrears of government units and agencies } \\
\text { to institutions or individuals; } \\
\text { - debt incurred by the subsidized } \\
\text { institutions which has clearly stated that } \\
\text { the debt to be repaid by the fiscal funds; } \\
\text { - debt that has been borrowed by the } \\
\text { China's Local Government Financing } \\
\text { Vehicles (LGFV) that also explicitly must } \\
\text { be repaid by fiscal funds. }\end{array}$ & $\begin{array}{l}\text { - higher level government transferring } \\
\text { financial debt (foreign lending debt, treasury } \\
\text { bond lending, agricultural comprehensive } \\
\text { development loans, and other financial } \\
\text { lending); } \\
\text { - the debt incurred by investment on gainful } \\
\text { competitive projects; } \\
\text { government-guaranteed financing platform } \\
\text { companies; } \\
\text { - direct debt of fund subsidies-institutions } \\
\text { and public utility companies; } \\
\text { - all the above funds should be deducted } \\
\text { from the financial funds to directly repay } \\
\text { debt. }\end{array}$ & $\begin{array}{l}\text { - debt of fund subsidies institutions } \\
\text { (such as universities, hospitals, etc.) for } \\
\text { the public good (basic) projects } \\
\text { borrowing; } \\
\text { - utilities companies for the public good } \\
\text { (basic) projects (water supply, heating, } \\
\text { gas, sewage treatment, and garbage } \\
\text { disposal, and so forth) borrowing; } \\
\text { - financing platform companies for the } \\
\text { public good (basic) projects in } \\
\text { construction borrowing; } \\
\text { - these are the unacknowledged } \\
\text { government assuming direct } \\
\text { responsibilities for repayment, nor debt } \\
\text { security provided (excluding the higher } \\
\text { level government transferring the } \\
\text { financial debt); } \\
\text { - the debts incurred from providing debt } \\
\text { guaranteed by the fund subsidies } \\
\text { institutions, utilities companies, and } \\
\text { financing platform companies for the } \\
\text { public good (basic) project } \\
\text { constructions (excluding the direct debt } \\
\text { reflected by the guarantee). }\end{array}$ \\
\hline
\end{tabular}

The Chinese government most recently defines the local government debts in terms of the second criteria. With regard to credibility of the official statistics, this paper supports the general view: maybe untrusted but valid. Moreover, during those interviews either officials or scholars give tacit consent to the authoritative category, on which this research is also based accordingly.

\section{The Importance and Unique Contribution of This Study}

Many scholars and students in China have tried to do research on the topic of Chinese local government debts. For example, Dr. Xie's (2013) doctoral thesis is “The Research of Local Government Debts of China” in which Dr. Xie mentioned that reducing the local government debts can effectively avoid the local government debt risk and is conducive for Chinese economic development in a stable and healthy manner (Xie, 2013). Dr. Hu's (2008) doctoral thesis is “Early Warning and Control on Regional Government Debt Crisis” (Hu, 2008). Dr. Hu (2008) felt that local government debts have a great impact on the implementation of local government budget as well as on the societal stability and maintaining normal national economic and social order (Hu, 2008). In Dr. Huang's (2007) doctoral dissertation "Research on Chinese Local Government Debt Management", she stated that such research has the importance of preventing its potential disruptive behavior toward the Chinese economic development, clarifying the relationship between the government and market boundary as well as improving government transparent. Lin (2011) illustrated the importance of government debts on the national credit as well as rationalizing the division of central and sub-national government in terms of who is in charge of what. In international realm, the Detroit's bankruptcy has taught a lesson to other local governments in the United States of America. The Greek crisis beginning in late 2009 has worried many European countries. In such a global environment, this study is all the more important. 
The unique contribution of this study is its holistic approach to address Chinese local government debts. In particular, the research intends to find out the root causes of the local government debt increasing and tries to find out solutions, such as reconstructing of the separate market and government responsibility, putting individual accountability for increasing local government debts in the future as well as establishing a local government debt management organization in the Chinese central government and so forth. The authors believe that these approaches will effectively curtain the growth impulse of local government debts and thus provide strategic solutions to the so far uncontrollable dramatic increasing of Chinese local government debts.

\section{Research Methods}

\section{Research Questions}

Research question one: What is the size of the Chinese local government debts?

In the first part of literature, this paper has cited some sources of the Chinese local government debts which are official. This research also wishes to collect more insights if this study can conduct empirical studies and to have a better estimation of the size of the Chinese local government debts.

Research question two: Are Chinese local government debts controllable?

Because of the alarming size and rapid increase of the Chinese local government debts even from the official sources in recent decade, it is a great concern whether Chinese local government debts are as uncontrollable as a wild horse without bridle, or if Chinese government has means to cope with it.

Research question three: Who or what caused the rapid increase of the Chinese local government debts?

The causes of the rapid increase of the Chinese local government debts especially in the past two decades or so are of great interests to the researchers. If this study can identify the major causes of whom or what is responsible for the sudden burst of the local debts, the government or the academic community probably has clues of how to solve the problem.

Research question four: Is it possible to have individual accountability for increasing local government debts in the future?

Since the large size and sudden increase of the local government debts are worrisome to many stakeholders, it is natural to consider whether it is possible to hold someone responsible for the increase of the local government debts in the future. If the central government can hold someone responsible for the increase of the local government debts, then it is likely the relevant officials will be more cautious when making decisions of increasing local debts. Therefore, the local government debts will not increase so fast.

Research question five: Will it be helpful to create a local government debt management organization in the Chinese central government?

If the answer is "Yes", where should this new organization be located? What are its major responsibilities?

\section{Research Methodology}

For this study, the researchers have read a number of scholarly papers in Chinese, including doctoral dissertations and master's degree theses. The researchers have also read some essays and papers in English. However, as an empirical study, the researchers have adopted the interview methodology with structured questions.

The researchers believe that the most informed people on the ground are Chinese local government leaders such as the town chief, county chief, or people who are in charge of local debts in the financial bureaus in different government levels such as county, prefecture city, and province. Through the researchers' connections, 
the researchers have interviewed eight government officials including three town chiefs, two county chiefs, two provincial level financial bureau leaders, and one policy analyst as well as one financial company CEO and five scholars from premier Chinese universities (the researchers believe that they are experts in Chinese local government debts) from May to June of 2015. These government officials are scattered in economically developed local governments as well as in less economically advanced local governments in China. Their opinions and views are extremely important to address the researchers' research questions and shape the researchers' policy recommendations.

\section{Research Results}

In this section, the researchers present the findings from the researchers' interviews with the officials and scholars targeted at the researchers' five research questions.

For research question one: What is the size of the Chinese local government debts?

The answers vary a lot. Overall, the government officials are much more cautious in terms of the size of the Chinese local government debts beyond the total of 16 trillion RMB by the end of 2014. Some indicate that the official-owned data of local government debts may be relatively small and not all-inclusive.

"Local governments are not likely to report all of their debts."

"There is hardly a precise and integrated database nationwide, but some rough general data."

"The real number can be somewhat larger, especially the contingent debt or the debt of Category III, mainly because of under-reporting of local governments."

Others claim that the data have already been collected at central government's command generally.

"The financial-related departments shall have the data, and the central government is able to get access to the data."

"It can be reckoned from the data of the central bank. However, it may be hard to tell local government debts from local SOEs' debts.”

"In general, the reported number is not smaller than the real number. But there is a diversion of the debts of Category I into the other two types of debts."

For research question two: Are Chinese local government debts controllable?

Most respondents believe that the size of the overall Chinese local debts is controllable. They believe that the Chinese government has huge resources to repay the debts with the sale of (or renting out) land or assets of SOEs.

"The debt is controllable indeed through a lens of balance sheet. The Chinese government possesses a large amount of assets legally, either tangible or intangible."

"An extensive debt crisis is not likely to happen."

"The public revenue from property sector can cover the repayment of debt's interest-the cost of government debt is relatively low."

"Local government debts are mainly used for public goods and service, not for business. And therefore risks do not exist.”

"Most of local government debts are domestic, and there is a strong support from the central government."

However, most interviewees worry about some risks in particular areas or localities.

"The mismatch of debt maturity leads to some short-term liquidity risk, though in a long run it may be healthy." 
"Some risks emerge at the grassroots level, albeit healthy provincial finances."

"In some less developed localities, public revenue from property sector is very limited. Given a big scale of debt, they are under massive pressure to repay the debt.”

"Two risks veil the local government debts: elusiveness and expansion, which are getting concentrated in areas with lower solvency, such as some areas in west China.”

"The risks in particular areas are controlled with current policies. In an objective sense, many resources could be used to deal with these risks. But they are deliberately prohibited by the central government, who intends to make small-scale debt default so as to heed a warning."

Still, one official considers the risk of local government debt as widespread.

"The risk exists across the country, since the development mode (borrowing to develop) is all the same. The less developed areas may have even smaller risks instead due to inability to borrow.”

For research question three: Who or what caused the rapid increase of the Chinese local government debts?

There are several perspectives for the rapid increase of the Chinese local government debts in recent decades.

It is widely believed that the official promotion mechanism is a key to the local debt burst. Official promotion is substantively linked to the economic performance of the region. Government officials have strong incentives to borrow money to boost the GDP, which helps their further promotions, while the debt problem would be left for the next term of the administration.

"The problem is partly owing to the official performance evaluation mechanism that counts on top-down inspections."

"It is associated with the achievement view of officials."

"Local officials demand promotion, with a strong desire to build more short-run achievements during a five-year term in office."

"The degree of official impulse is related to the official rank. The officials in counties to a largest extent desire achievements because of their age and needs of promotion."

"When the risks emerge, the officials probably just left office."

Economic development in general and infrastructure construction in particular seem to be a common reason for the rapid accumulation of local debts.

"The economic development oversteps the law of the market. Local governments stress infrastructures, but ignore industries.”

"Local governments construct a great number of industry parks, but some then cannot attract business and investment as expected. Therefore, the governmental investment in infrastructures tends to be hard to return, which causes the problem of debts."

"Some local governments jump to planning without sufficient investigations, out of tune with urbanization development."

Many respondents argue that central government's policies and attitude may partly account for rapid expansion of local governmental debts.

"Compared with the local governments, the central government shall be largely blamed to the problem of local governmental debts for its acquiescence and negative attitude. During the 2008 crisis, the central government even stimulates the local governments to borrow money via sorts of channels.” 
"It is the central government's requirement in 2008 and 2009. Moral hazard occurs because the central government bears some of the burden."

"The financial policy made by the central government exerts great pressure on the local governments, leading to the debts."

"During the 2008 crisis, the central government just required local governments' investment. It did not demand return and payback then.”

"Before the crisis, it is the government that asks banks for lending; however during the crisis, it is bank that asks the government for borrowing."

"The recent pressure of repayment is related to the then four-trillion strategy."

Some share the view that the growth of local governmental debts is resulted from the slower and slower economic growth.

"When the economic growth becomes slowing down, government's revenue growth decreases concurrently. However government's expenditure features heavily in rigidity. Non-profit programs are related to employment, and public investments to economic growth, neither of which can be cut off."

"The key problem is of fiscal balance."

Some interviewees pointed out the 1994 tax for fee reform, which increased the expenditure responsibility of local governments while decreasing the capacity of levying the tax revenue.

"A majority of taxes, about 70\%, are paid to the central government, while the local governments have to deal with most of investment to infrastructure. The unreasonable allocation between the central and the local leads to this problem."

"The 1994 reform left power and capacity mismatched.”

"Local governments lack financial resources after the 1994 reform."

"The power-capacity mismatch catalyzed the problem of local government debts indeed. The top-down intergovernmental transfer payment intensifies the mismatch in part, given the hukou system. The migrant population is provided with the public service in the locality of destination, while the transfer is paid to the government of original hukou domicile (registered place of residence), leading to payment imbalance.”

LGFVs are widely regarded as a way of local governmental financing, not a reason for local governmental debts.

"The business of LGFVs is forced. They have not choices. They are controlled."

"LGFVs act just as instruments for financing."

"More than 80 percent of LGFVs' business is for governmental financing, mainly to non-profit programs."

"LGFVs carry a risk of the local governmental debts: uncertainty."

None of the respondents agrees on the idea that the problem of local governmental debts is, even in part, owing to public general expenditure to civil servants.

"As a matter of fact the general budget is in short. However, the number is not that large to explain the growth of local governmental debts.”

"The salary to civil servants is guaranteed nationwide. In the poverty localities, there is transfer payment from the central government. The budget is able to cover the general expenditure for certain.”

"With a comparison between our administrative function and the number of civil servants, Chinese government is a relatively small government to some extent. The percentage of general expenditure to civil servants to the overall government expenditure is not very high.” 
"No local government in China maintains general operation via debts."

"All of local governmental debts are earmarked. The local governments dare not to embezzle."

"The money from debts cannot flow to the account of salary to civil servants."

For research question four: Is it possible to have individual accountability for increasing local government debts in the future?

Almost all of the respondents declare that the local government officials should be blamed to a degree. Debt issue should be a factor in performance evaluation.

"The performance evaluation mechanism needs adjusting if we are willing to tackle the problem of local governmental debts thoroughly."

"It is necessary to investigate and ascertain the accountability."

"The investigation of accountability can take effect of supervision, as well as deterrence."

"The investigation is to warn the local officials to pay further attention to the government's debts."

Some interviewees talk about the criteria of officials' accountability of debts.

"Off-office auditing should be emphasized, both on efficiency of debts and on rationale of debts."

"The accountability depends on the scale of debts. The rationale should be well-explained, and consistent with requirements of the central government."

Some respondents point out that only the officials in office are to be investigated.

"Only the officials in office, not the former, will be blamed."

"As for the debt already issued before, we investigate the responsibility of debt managers, not the accountability of debt issuers."

Some respondents believe that in practice, it will be very difficult if it is not impossible to hold individual officials to be responsible for the debt increase.

"The accountability of the debt to develop local economy is unlikely to be traced."

"Off-office auditing is to strengthen political awareness. Today the objective has already achieved."

"It is to assure the economy to a soft landing that the central government considers debt management as a factor of performance evaluation. Development is still the top priority."

Nevertheless, one respondent worries that accountability cannot solve the underlying problem.

"Accountability is very easy to avoid when the officials take advantage of SOEs."

For research question five: Will it be helpful to create a local government debt management organization in the Chinese central government?

The responses are negative. Every interviewee hardly believes that it cannot do with the existing problem of local governmental debts to establish a debt management department or agency under the State Council (the Chinese central government).

"The imaginary new agency does not have as much authority as the Ministry of Finance to supervise local officials.”

"The debt management department's function is very limited. The number of professional staff might increase. However its authority must be less than the Ministry of Finance. The Ministry of Finance can make use of its unique resources to negotiate with other departments and agencies.”

"Such institutional reforms of the State Council may have some beneficial effect on supervision, but it is not at the top of a list." 


\section{Analysis and Discussion}

The issue of Chinese local government debts is an important yet sensitive topic in China. On the one hand, various levels of Chinese local governments need financial resources for a wide range of purposes. On the other hand, the seemingly uncontrollably large increase of local government debts has garnered spotlights from government officials, scholars, investors, and the media alike. The researchers' investigation of this issue has led the researchers to propose some suggestions in order to either solve or at least contain the rapid increase of the local government debts.

Five recommendations:

First, the researchers recommend drawing a clear line of demarcation between the government and the market.

If the researchers study the compositions of the local government debts carefully, it is not difficult to find out that the major sources of the local debts are derived from economic activities. If the government behaves ideally following the market mechanism, many of the debts should not be generated in the first place. However, as the researchers know, not long after the establishment of the People's Republic of China (PRC) in 1949, PRC followed suit of the former Soviet Union and adopted a command economy. In such a system, the majority of economic activities belong to the State-owned Enterprises and the free market is marginal. Since 1978, the whole country was re-oriented to economic development. In 1992, the central government announced that the PRC was in the primary stage of socialism and China should build socialist market economy with Chinese characteristics. Even in the political and administrative arenas, China has conducted seven rounds of administrative reforms ever since 1978 (1982, 1988, 1993, 1998, 2003, 2008, and 2013). Those administrative reforms have aimed at the transition of the government functions (Straussman \& Zhang, 2001; M. Zhang, 2006). So far, the administrative reforms in China are far from completed. Changing the value, idea, function, and procedure of the government (officials) is a long-term goal. Commentators can easily find out that the Chinese government nowadays still intervenes the market behavior heavily. Thus, drawing a clear line of demarcation between the government and the market is still a long journey. Nevertheless, if government can clarify and faithfully respect the borderline between itself and the market, the debt increase will shrink largely.

From a systemic point of view, the Chinese society has been in transition from previous socialist command economy to the primary stage of socialist market economy (the milestone year was in 1992). Even nowadays, the boundary between the government and the market is not quite clear, which has caused a number of problems. Some provide the argument that the government gets involved with the market that increases the government expenditure, leading to an expansive scale of governmental debt given constant revenues (Guo, 2001; An, 2002). This paper does not focus on why and how to constrict the government's involvement with the market. However more important, the legislation of the boundary between Chinese government and the market cannot be found, or does not exist at all. The first step is to set forth demarcation of the government's lawful intervention into the market, which underlies the second suggestion. Unless this could come true, the power within the government would no longer become clarified, given an ambiguous power of the government as a whole.

Second, the researchers recommend reforming the current tax sharing mechanism between the central and local governments. 
The researchers' studies have revealed that the 1994 tax for fee reform has largely increased the proportion of central government's fiscal revenue (M. Zhang, 2006), while decreased its fiscal responsibilities gradually. As a result of the 1994 reform, the central share of tax revenue jumped from 22 percent in 1993 to 55.7 percent in the following year (World Bank, 2002; also see Table 1). The result is that local government's revenue decreased while local government's expenditure increased. The increase gap of low revenues and high expenditure has pushed the local governments to take on increasing debts to balance their budgets. Still the centralization of capacity to the central government can relieve the economic inequality among different districts; the decentralization of power to local governments may improve the efficiency of public service provision. The intergovernmental imbalanced power-capacity relationship shall be settled by transfer payment (Lei, 2012).

As the tax resources get centralized into the central government, intergovernmental transfer payment increases correspondingly. A roughly 70 percent of the central government's revenue is transferred downwards to local governments (Anonymity, 2014). The transferring financial debt can also be regarded as a particular kind of central government transfer payment to local governments. But intergovernmental transfer payment is born with inevitable demerits regarding transparency, efficiency, and consistency (Gu, 2006). In view of incrementalism, the transfer does not take into account the financial balance gulf in different localities (Lei, 2012). The special (zhuanxiang) transfer payment of earmarked funds compels local governments to raise most of the funds, which is termed "central government's power over local government's capacity (zhongyang chu zhengce, difang chu zijin)".

It is time for the central government to reform its current practice of revenue sharing with the local governments. Any further behavior of wherein the "central government hosts a banquet while local governments pay the bill" should be very viewed with extreme caution. This is like the unfunded mandate in the USA, which is unpopular among the sub-national governments.

All in all, the problem of local governmental debts is uncertainty and arbitrariness of the power of local governments, and by extension too much central government's intervention of excessive tasks to local governments. The power-capacity reform shall live up to the expectation of rebalance. The legitimized allocation of power between the central government and local governments should be prioritized, and then the adjustment of governmental revenue system. China has already proposed to "appropriately increase the authority of office and responsibility of expenditure of the central government" and to "maintain the overall stability of the current financial pattern of the central and local governments". "The central government can delegate some expenditure responsibilities to local governments through transfer payments" (Anonymity, 2014).

Third, this research recommends holding the relevant officials responsible for the illegal increase of the local government debts.

Unlike in western countries where the citizens elect the top politicians in every level of government, Chinese leaders are appointed or selected by the higher level Chinese Communist Party (CCP) organizations. The Chinese Communist Party can easily promote or demote or even fire its government officials. This systematic difference between China and western democratic countries results in quite different motivation between Chinese leaders/officials and the western politicians. The western politicians have to be responsible for their constituency, while Chinese leaders/officials have to be responsible for the higher level Chinese Communist Party. 
In the past, more than three decades, China has adopted a grand policy of reform and opening to the outside, and focused on economic development. Therefore, an important indicator of government officials' performance is GDP growth. Gradually, local government officials have "found" that borrowing money to drive economic development is a very effective way to stimulate GDP growth, while individual officials do not need to be responsible for the sudden large increase of the government debts. As for the evaluation of the grass root bureaucrats, Huang (2014) has conducted case studies in which he identifies 54\% of a performance measurement is related to economic activities. Many government leaders/officials have been promoted to the higher level of governments and the large debt increase has to be left for the next term of the administration to deal with. If the impulse of borrowing money to stimulate the economy is not contained, the large increase of local government debts cannot be stopped. In these empirical studies, the researchers have asked the interviewees to share their opinion on whether it is possible to hold some officials responsible for the local government debts. It was surprising to discover that all respondents who answered this question believe that it is difficult if it is not impossible to hold relevant government officials responsible for the increase of the local debts. Nevertheless, the researchers perceive that it is both necessary and possible to devise a system/mechanism to hold relevant government officials' (especially the top leaders of every level of governments) responsibility if the local governments under their domain have large and sudden large increases of the debts. If this accountability mechanism can be tracked to a life-long process, the motivation of borrowing money to boost the local economy can be controlled. To do so, the corresponding level of the People's Congress should pass relevant laws and the Chinese Communist Party Organizations should also issue relevant regulations. It is plausible that local government officials may have an incentive to say that they do not want oversight. Thus their views on this matter should not necessarily be surprising if motivated reasoning is involved.

Fourth, the researchers recommend establishing an organization in the central government to manage the Chinese local government debts.

By June of 2013, Chinese local government debts had reached more than 10 trillion RMB. Though Chinese central government leaders from time to time have announced that the central government would not take care of the local government debts problem if the locality cannot repay the debt in the end, the respondents and the researchers believe that this is not a credible threat: if the local government debts cannot be repaid, the central government will bail them out. China is a politically unitary country. The simple truth is that the central government cannot ignore the problem of the local government. As some respondents argue that central government's policies and attitude should take part in the responsibility of the current dilemma of local governmental debts. As early as the beginning of the 21st century, the idea of a unified debt management department within the State Council has already been put forward (Guo, 2001). Considering the limitation of establishing an independent ministerial agency, the researchers propose that the central government should establish an organization to manage the Chinese local government debts. This organization should be ideally located within the Ministry of Finance as a specific bureau such as local debt bureau. The major function of this bureau is to approve the annual debt quota of each province, monitor the debt variation of each province, and propose regulations of debt related policies (to be approved by the National People’s Congress).

\section{Conclusions}

From Table 1, it can be seen that the Chinese government debts began to accumulate in the 1980s and the 
Chinese local government debts started to have a sudden increase from 1994 largely attributed to the 1994 tax for fee reform. By the end of 2004, the Chinese local government debt reached 2.5 trillion RMB. More worrisomely, the researchers see a rapid increase of local debts in the past decade from 2.5 trillion RMB in the end of 2004 to more than 23 trillion RMB in the end of 2014. It is almost impossible to grasp the true picture of the local government debt in the whole country. Nevertheless, the researchers are afraid that this debt issue might burst in the foreseeable future. While borrowing money has been playing an important role in stimulating the local economy, there are a number of negative impacts to the country.

Huge amount of local debts have influences on the Chinese macro economy, on banks who have lent money to the local governments, on overall Chinese government authority and reputation, to international investment, and on social stability (Xie, 2013; Lin, 2011). There are increasing promising risks that some local governments cannot repay the debts or the interest of the debt. If some local government breaking contracts or cannot keep their promises to pay the debt or the interests on time to the borrowers, it could be disastrous, leading to large scale demonstrations and social instability.

According to this research, the greatest problem is that most government officials and scholars have not realized that the Chinese local government debt is an imminent issue that needs to be taken care of immediately. If the Chinese government does not curtail this dangerous trend of taking on debt for various purposes over the next a few years, the situation may spiral out of control. The researchers can identify the following root causes and potential solutions for Chinese local government debts. First, as China has tried to redefine the government functions in the stage of socialist market economy with Chinese characteristics, the ongoing adjustment of the functions between government and the market needs to have an explicit borderline. Thus, the government should no longer intervene in the areas which belong to the competitive market. Second, the 1994 tax for fee reform needs to be re-examined and further adjustment is necessary to distribute the local government higher percentage of revenue sharing. Third, the Chinese Communist Party (CCP) and government should stipulate relevant rules or regulations to promote or demote CCP or government leaders/official associated with the local debt level. The researchers believe that the new mechanism will effectively reduce the motivation of irresponsible money borrowing. Fourth, the researchers believe that an organization in the central government is necessary to manage the local debts. Its function should focus on approving, monitoring, and proposing relevant rules and regulations and managing the local debts. Right now, no such organization is in charge of the Chinese local government debts, and even the size and scale of the local government debts is a mystery. If the Chinese CCP and government can adopt the above four approaches, the researchers are optimistic that the Chinese (local) debt problems will be solved.

The Chinese central government has paid great attention to the issue of its local government debts. For example, since 2013 tens of regulations have been issued such as "National Governmental Debts Auditing Result (2013)”, "PRC Budget Law” (amendment passed in August 2014), “Opinions on the Strengthening of Government Debt Management by the State Council (2014)", and "Tentative Measures of Local Government Issuing General Bonds (2015)”. Whether these regulations will be effective to suppress the dramatically increase of local debts is uncertain.

This study focused more on grand strategy and guidelines to target at the rapid increase of the Chinese local government debts in recent decades. Detailed steps and measures are needed to implement these strategies. 


\section{References}

An, X. (2002). Root causes and solution measures on local government contingent debts. Contemporary Finance and Economics (Chinese), 5, 34-39.

Anonymity. (2014). The causes of local government debts: Ranking of provincial government debts. Retrieved from www.jqgc.com/jmda/44777.shtml

Bloomberg News. (2015). China local government debt surge boosts focus on PBOC help. Retrieved from http://www.bloomberg.com/news/articles/2015-04-27/china-local-government- debt-surge-boosts-focus-on-pboc-help

Costa, P. (2015). China's total debt load equals 282\% of GDP, raising economic risks. The Wall Street Journal. Retrieved from http://blogs.wsj.com/economics/2015/02/04/chinas-total-debt-load-equals-282-of-gdp-raising-its-economic-risks/

Feng, B. (2013). Local governmental debt risk and prevention. Chinese Finance (Chinese), 7, 53-55.

Gu, J. (2006). Research on local governmental debts and risk prevention measures. Economic System Reform (Chinese), 1, 10-15. Retrieved from http://finance.ce.cn/rolling/201502/02/t20150202_4490893.shtml

Guest Post. (2014). China's debt time bomb the fall out. Financial Times. Retrieved from http://blogs.ft.com/beyond-brics/2014/12/02/guest-post-chinas-debt-time-bomb-the-fall-out/

Guo, L. (2001). Research on the issue of Chinese local government debt risk. Doctoral Dissertation of Xiamen University (Chinese). Retrieved from http://www.china.org.cn/chinese/2014-01/17/content_31226494_5.htm

Haitong. (2014). Haitong: Actual local government debts: 13.3 trillion RMB. Retrieved from http://business.sohu.com/20140516/n399667394.shtml

He, W. (2014). Be on guard against local government debt burst in 2015 . Retrieved from http://finance.qq.com/a/20141230/017621.htm

Hu, G. (2008). Research on local governmental debt warning and control. (Doctoral dissertation of Jilin University) (Chinese).

Huang, F. (2011). Research on Chinese local government debt management. (Doctoral dissertation, Institute of Public Finance, Ministry of Finance of China).

Huang, X. (2014). Study on township leading bodies and leading cadres performance evaluation system—Taking Cangnan county as an example. (Master degree thesis, East China University of Science and Technology) (Chinese).

Jia, K., Liu, W., Zhang, L., Shi, Y., \& Sun, J. (2010). Local government debts risk and countermeasure of China. Economic Research Reference (Chinese), 14, 2-28.

Kuijs, L. (2010). China's local government debt-What is the problem? The World Bank. Retrieved from https://blogs.worldbank.org/eastasiapacific/china-s-local-government-debt-what-is-the-problem

Kwong, M. (2013). PBOC sounds warning over local government loans. South China Morning Post. Retrieved from http://www.scmp.com/business/banking-finance/article/1190174/pboc-sounds-warning-over-local-government-loans

Lei, C. (2012). The causes of Chinese local government debt increase: Systemic interpretation frame. Economic Research Reference (Chinese), 38, 23-32.

Li, S., \& Lin, S. (2011). The size and structure of China's government debt. The Social Science Journal, 48, 527-542.

Lin, J. (2011). On the problem of local government debt in China. (Doctoral dissertation, at Northeast Finance and Economic University) (Chinese).

McMahon, D. (2015). China allows local governments to issue $\$ 160$ billion of bonds. The Wall Street Journal. Retrieved from http://www.wsj.com/articles/chinese-local-governments-to-issue-160- billion-of-bonds-to-repay-debt-1426226789

Nagao, H. (2015). Debt time bomb risk of made in China fiscal cliff grows. NIKKEI Asian Review. Retrieved from http://asia.nikkei.com/Politics-Economy/Economy/Risk-of-Made-in-China-fiscal-cliff-grows

Quanguo Zhengfuxing Zhaiwu. (2013). National governmental debts auditing result. Retrieved from http://www.audit.gov.cn/n1992130/n1992150/n1992500/3432077.html

Shen, W. (2014). The Logic (or illogic) of China's local government debts out of control—Law, governance or other perspectives. Hong Kong Law Journal, 44(3), 887-916.

Song. L. (2013). Enormous local government debt a timebomb for China. The Guardian. Retrieved from http://www.theguardian.com/local-government- network/2013/aug/09/chinese-local-government-debt-timebomb

Straussman, J., \& Zhang, M. (2001). Chinese administrative reforms in international perspective. The International Journal of Public Sector Management, 14(4 \& 5), 411-422.

Talley, I. (2014). China may face US-style financial crisis. World Bank Economist. Retrieved from http://blogs.wsj.com/economics/2014/06/17/world-bank-economist-china-may-face-us-style-financial-crisis/ 
Wei, L., \& Davis, B. (2015). Debt that once boosted its cities now burdens China. The Wall Street Journal. Retrieved from http://www.wsj.com/articles/debt-that-once-boosted-its-cities-now-burdens-china-1422415981

Wildau, G. (2015). China mulls plan to boost demand for local government debt 2015. Financial Times. Retrieved from http://www.ft.com/cms/s/2/a8a632a4-ed8d-11e4-a894-00144feab7de.html\#axzz3bB03G82E

World Bank. (2002). National development and sub-national finance-A review of provincial expenditure. Beijing: Poverty Reduction and Economic Management Unit, East Asia and Pacific Region.

Xie, Q. (2013). The research of local government debt of China. (Doctoral dissertation, Research Institute for Fiscal Science, Ministry of Finance, PRC).

Yan, C. (2012). China faces debts crisis cliff. Retrieved from http://blog.sina.com.cn/s/blog_779a5b78010197tg.html

Zhang, H. (2006). Research on the issue of government contingent debt (Doctoral Dissertation of Northeast Finance University) (Chinese).

Zhang, M. (2006). Assessing China’s 1994 fiscal reforms: An intermediate report. Journal of Public Budgeting, Accounting \& Financial Management, 18(4), 453-479.

Zhang, M. (2013). China's local government financing vehicles (LGFV): Seven things you should know about China's local debt bomb. International Business $\quad$ Times. Retrieved from http://www.ibtimes.com/chinas-local-government-financing-vehicles-lgfv-7-things-you-should-know-about-chinas-local-debt

Zhao, F. (2004). The probable debt risk review of China's public finance. Economic Research Reference (Chinese), $23,39-45$.

Zhao, Y. (2011). Research on local government debts. Economic Research Reference (Chinese), 38, 2-22.

Zheng, C. (2012). The real risk of Chinese local government debts: The risk beyond default risk. Public Administration Review (Chinese), 4, 52-76. 